\title{
Anti-inflammatory and Anti-necrotic Effect of Lectins from Canavalia ensiformis and Canavalia brasiliensis in Experimental Acute Pancreatitis
}

Samara Rodrigues Bonfim Damasceno Oliveira

Universidade Federal do Ceara

Álvaro Xavier Franco

Universidade Federal do Ceara

Marielle Pires Quaresma

Universidade Federal do Ceara

Cecília Mendes Morais de Carvalho

Universidade Federal do Ceara

Fabrícia da Cunha Jácome Marques

Universidade Federal do Ceara

Patrícia da Silva Pantoja

Universidade Federal do Ceara

Vanessa Azevedo Mendonça

Universidade Federal do Ceara

Vinicius José da Silva Osterne

Universidade Federal do Ceara

Jorge Luis Almeida Correia

Universidade Federal do Ceara

Ana Maria Sampaio Assreuy

Universidade Estadual do Ceara

Marcellus Henrique Loiola Pontes de Souza

Universidade Federal do Ceara

Kyria Santiago do Nascimento

Universidade Federal do Ceara

Benildo Sousa Cavada

Universidade Federal do Ceara

David Neil Criddle

University of Liverpool

Pedro Marcos Gomes Soares ( $\square$ pedrogsoares@gmail.com )

Universidade Federal do Ceara https://orcid.org/0000-0003-0606-2539 


\section{Research Article}

Keywords: Lectins, Anti-inflammatory, Anti-necrotic, Acute Pancreatitis.

Posted Date: May 27th, 2021

DOl: https://doi.org/10.21203/rs.3.rs-172690/v1

License: (c) (i) This work is licensed under a Creative Commons Attribution 4.0 International License. Read Full License

Version of Record: A version of this preprint was published at Glycoconjugate Journal on March 3rd, 2022. See the published version at https://doi.org/10.1007/s10719-022-10048-w. 


\section{Abstract}

Lectins isolated from Canavalia ensiformis (ConA) and Canavalia brasiliensis (ConBr) are promising molecules to modulate cell death. Acute pancreatitis, characterized by acinar cell necrosis and inflammation, presents significant morbidity and mortality. This study has investigated the effects of ConA and $\mathrm{ConBr}$ on experimental acute pancreatitis and pancreatic acinar cell death induced by bile acid. Pancreatitis was induced by retrograde pancreatic ductal injection of $3 \%$ sodium taurocholate (Na-TC) in male Swiss mice. ConA or ConBr (0.1, 1 or $10 \mathrm{mg} / \mathrm{kg}$ ) were intravenously applied to mice $1 \mathrm{~h}$ and $12 \mathrm{~h}$ after induction. After 24 hours, the severity of pancreatitis was evaluated by serum amylase and lipase, histopathological changes and myeloperoxidase assay. Pancreatic acinar cells were incubated with ConA $(200 \mu \mathrm{g} / \mathrm{ml})$ or ConBr $(200 \mu \mathrm{g} / \mathrm{ml})$ and taurolithocholic acid 3-sulfate (TLCS; $500 \mu \mathrm{M})$. Necrosis and changes in mitochondrial membrane potential $(\Delta \Psi \mathrm{m})$ were detected by fluorescence confocal microscopy. Treatment (post-insult) with ConA and ConBr decreased pancreatic damage caused by retrograde injection of $\mathrm{Na}-\mathrm{TC}$ in mice, reducing pancreatic neutrophil infiltration, edema and necrosis. In addition, ConA and ConBr decreased pancreatic acinar cell necrosis and depolarization of $\Delta \Psi \mathrm{m}$ caused by TLCS. The inhibition of necrosis was prevented by the lectin domain blockade; molecular docking analysis showed strong interaction of ConA and ConBr crystal structures with mannose residues. In conclusion, ConA and $\mathrm{ConBr}$ markedly inhibited in vitro and in vivo damage, effects partly dependent on the interaction with mannose residues on acinar cells. These data support the potential application of these proteins for treatment of acute pancreatitis.

\section{Introduction}

Acute pancreatitis is a potential severe inflammatory disease of the exocrine pancreas presenting significant morbidity and mortality. The most common cause is cholelithiasis, accounting for $35 \%-60 \%$ of cases [1]. Acute biliary pancreatitis is characterized by elevated pancreatic amylase and lipase, tissue necrosis and severe pancreatic inflammation, which may lead to a systemic inflammatory response syndrome, multiple organ dysfunction and death [2].

According to the revised 2012 Atlanta Classification of Acute Pancreatitis, the presence of necrosis and the number of organs affected by the subsequent inflammatory response determines the disease severity (mild, moderate, severe) and dictates the short-term and long-term management of the patients [3]. The severity of experimental pancreatitis is correlated with the extent of cell necrosis and inversely with apoptosis [4-6].

In isolated pancreatic acinar cells, bile acids such as taurolithocholic acid 3-sulfate (TLCS), cause necrosis due to a sustained increase of cytosolic calcium ([Ca2+]C) via activation of the Gpbar1 G-protein receptor [7] $\mathrm{Ca} 2+$ release from intracellular stores and inhibition of the sarco-endoplasmic reticulum Ca2+-adenosine triphosphatase (SERCA) pump [8] leading to premature intracellular enzyme activation, cell vacuolization, mitochondrial depolarization and decrease in ATP production [9-11]. However, currently there is no specific therapy to treat the disease. 
Leguminous lectins of the Diocleinae subtribe, a class of carbohydrate-binding proteins, have received increasing attention because of their various biological properties [12]. ConA and $\mathrm{ConBr}$, isolated from the seeds of Canavalia ensiformis and Canavalia brasiliensis, possess binding specificity to residues of glucose/mannose and share $90 \%$ structural similarity, and are considered promising molecules since they possess a variety of biological functions, including neuroplasticity [13-17]; modulation of cell death, and antiproliferative effects on tumor cells $[18,19]$. They promote apoptosis in human leukemic cells lines, in a mitochondrial-dependent manner, while preserving healthy cells [20]. In addition, these lectins exert immunomodulatory and antinociceptive properties in experimental models in vivo [21-24].

However, the potential of these lectins to prevent cell necrosis and inflammation in acute pancreatitis has not been fully investigated. This study aimed to evaluate the effects of ConA and ConBr in the mice experimental acute biliary pancreatitis induced by taurolithocholic acid 3-sulphate (TLC-S) and assess the involvement of the lectin-carbohydrate interaction.

\section{Materials And Methods}

\section{Lectin Purification and Dissolution}

The lectins were purified from seeds of the leguminous plants Canavalia ensiformis (L.) DC. (Jack bean) (ConA) and Canavalia brasiliensis MART (ConBr) by affinity chromatography $[25,26])$ both possessing binding-specificity to D-glucose and D-mannose. After purification, the lectins were dialyzed in distilled water, lyophilized and dissolved in $0.9 \% \mathrm{NaCl}$ (sterile saline) immediately prior to use.

\section{Chemicals}

Collagenase was purchased from Worthington Biochemical Corporation (Lakewood, NJ, USA); TMRM and Hoechst 33342 from Molecular Probes (Eugene, Oregon, USA); TLCS, Na-TC, PI and a-methylmannoside from Sigma (St. Louis, MO).

\section{Animals}

Male Swiss mice (20-25g), provided by the Animal Housing Facility of the Department of Physiology and Pharmacology of the Medical School of the Federal University of Ceará, were housed in an environment with controlled temperature and luminosity, with a $12 \mathrm{~h}$ light/dark cycle and free access to food and water. All procedures were in accordance with the guidelines of the National Council for the Control of Animal Experimentation (CONCEA) and approved by the Animal Use Ethics Committee (CEUA) of the Federal University of Ceará (protocol n 99/2013).

\section{Experimental Acute Pancreatitis}

Acute pancreatitis was induced by retrograde pancreatic ductal injection of $3 \%$ sodium taurocholate (NaTC) $(5 \mu \mathrm{L} / \mathrm{min}$ for 10 minutes via infusion pump) in adult mice $(25-28 \mathrm{~g})$. The control groups received retrograde pancreatic ductal infusion of saline (Sal Group) alone or the surgical procedure without 
infusion, denominated Sham group [27], ConA or $\mathrm{ConBr}(0.1,1$ or $10 \mathrm{mg} / \mathrm{kg}$ i.v.) were applied as treatment to mice $1 \mathrm{~h}$ and $12 \mathrm{~h}$ after pancreatitis induction. After 24 hours, the animals were sacrificed, and the blood was collected for estimation of pancreatic enzymes amylase and lipase and the pancreas removed for myeloperoxidase assay (MPO) and histopathological analysis.

\section{Histopathological Evaluation}

Pancreatic tissue was fixed in 10\% formalin, embedded in paraffin and stained (hematoxylin and eosin $\mathrm{H} \& \mathrm{E})$. Evaluation was performed on 10 random fields (x200) by a blinded investigator grading edema, inflammatory cell infiltration, and acinar necrosis (scale of $0-3)$ expressed as mean \pm SEM $(\geq 8$ mice/group).

\section{Myeloperoxidase Activity}

Myeloperoxidase (MPO) activity was determined as described [28]. Pancreatic tissue was homogenized, resuspended in $100 \mathrm{mmol} / \mathrm{L}$ phosphate buffer $(\mathrm{pH} 6.0)$ containing $0.5 \%$ hexadecyltrimethyl ammonium bromide and centrifuged for 20 minutes at $16,000 \mathrm{~g}$. MPO activity was measured in supernatants $(3,3,5,5-$ tetramethylbenzidine substrate with $1 \% \mathrm{H} 2 \mathrm{O} 2$ ). Absorbance was measured at $450 \mathrm{~nm}$ and MPO calculated as the difference between absorbance at 0 and 2 minutes.

\section{Amylase Measurement}

Serum amylase was determined by colorimetric assay (Labtest ${ }^{\circledR}$, Brazil) following the manufacturer's instructions. For the amylase assay, after the addition of $500 \mu \mathrm{l}$ of the substrate, the samples $(10 \mu \mathrm{l})$ were incubated in a water bath at $37^{\circ} \mathrm{C}$ for 2 minutes, followed by addition of $500 \mu \mathrm{l}$ of the color reagent and $4 \mathrm{ml}$ of distilled water. After mixing and waiting 5 minutes, absorbance was determined at $660 \mathrm{~nm}$.

\section{Lipase Measurement}

Serum lipase was determined by colorimetric assays (Bioclin ${ }^{\circledR}$, Brazil), following the manufacturer's instructions. For this, $1 \mathrm{ml}$ of the reagent $1,50 \mu \mathrm{l}$ of reagent 2 and $100 \mu \mathrm{l}$ of reagent 3 were added to the $50 \mu \mathrm{l}$ of the sample. Samples were placed in $37^{\circ} \mathrm{C}$ water bath for 2 minutes with $100 \mu \mathrm{l}$ of reagent 4 , homogenized and incubated at $37^{\circ} \mathrm{C}$ for 30 minutes. Two milliliters of Reagent 5 were added, and samples homogenized and allowed to stand for 3 minutes at room temperature. The material was centrifuged at $3500 \mathrm{rpm}$ for 5 minutes and the absorbance of the supernatants determined at $410 \mathrm{~nm}$.

\section{Cell Preparation and Solutions}

Pancreatic acinar cells were isolated from the excised pancreas of male mice (8-12 weeks old) with purified CLSPA collagenase (Worthington Biochemical Corp. $\left.{ }^{\circledR}\right)$. The experiments were performed at room temperature $\left(23-25^{\circ} \mathrm{C}\right)$ and the cells were used within 4 hours after isolation. The extracellular solution contained (in mmol/l): $140 \mathrm{NaCl} ; 4.7 \mathrm{KCl} ; 1.13 \mathrm{MgCl} 2 ; 1 \mathrm{CaCl} 2 ; 10$ D-glucose; and 10 HEPES (4- (2hydroxyethyl) -1-piperazinoethanesulfonic acid), adjusted to $\mathrm{pH} 7.35 \pm 0.1$ [29]. 


\section{Role of ConA and ConBr on Cellular Necrosis and Mitochondrial Membrane Potential $(\Delta \Psi \mathrm{m})$ : Involvement of Lectin Domain}

Cells were incubated for $1 \mathrm{~h}$ with ConA $(200 \mu \mathrm{g} / \mathrm{ml})$ or $\operatorname{ConBr}(200 \mu \mathrm{g} / \mathrm{ml})$ and stimulated for 30 minutes with TLCS $(500 \mu \mathrm{M})$. Necrotic cell death was detected by confocal microscopy (FluoViewTM $1000-$ Olympus) using propidium iodide (PI, $1 \mu \mathrm{M} / \mathrm{L}$ : excitation $488 \mathrm{~nm}$, emission 630-693 nm), cell membrane impermeable nucleic acid intercalator. In separate experiments changes in mitochondrial membrane potential $(\Delta \Psi \mathrm{m})$ were performed using the fluorescent probe tetramethylrodamine methylester (TMRM $100 \mathrm{nM}$ - excitation/emission: 543/550-650, 15 min incubation), the accumulation of which in mitochondria is driven by the highly negative inner mitochondrial membrane potential. Total cell number was detected using nuclear Hoechst 33342 (50 $\mu \mathrm{g} / \mathrm{mL}$ : excitation $364 \mathrm{~nm}$, emission 405-450 nm) [10]. The percentage of necrosis was calculated from the ratio of cells stained with Hoechst 33342 and propidium iodide (PI). The percentage (\%) of mitochondrial depolarization was calculated from the ratio of cells labeled with Hoechst 33342 and TMRM, in which a decrease in relative fluorescence of TMRM represented mitochondrial depolarization. Cell counts were performed in triplicate in 15 high-power fields. The involvement of the lectin domain on cellular necrosis was assessed by the prior incubation of ConA and $\mathrm{ConBr}\left(37^{\circ} \mathrm{C} ; 1 \mathrm{~h}\right)$ with $0.2 \mathrm{M}$ of their binding sugar a -methyl-D-mannoside (a-MM).

\section{Molecular Docking}

Docking studies were carried out to predict the binding affinity using scoring functions, hydrogen bonds and hydrophobic interactions. Table 1 and Table 2 (supplementary results) contain the score values. LigPlot + v. 1.4.5 [30] was used to generate two-dimensional representations, and PyMol (Schrodinger LLC) was used to generate the figures.

Monosaccharides (a-D-mannose, a-D-glucose, alpha-methyl-D-mannoside, N-acetyl-D-glucosamine and Nacetyl-D-mannosamine) and N-glycans (Figure S1) were docked with ConA (PDB id: 4FP5) and ConBr (PDB id: 4H55) using the CLC Drug Discovery Workbench software v. 3.0 (CLC Bio; Boston; MA; USA). Protein optimization, ligand preparation and grid generation were performed prior to target ligand docking. The radius selected for docking was $15 \AA$ around the carbohydrate recognition domain for both proteins and the number of iterations was set to 5000 for monosaccharides and 200 for complex glycans. CLC Drug Discovery Workbench applies a built-in precision mode to determine the favorable binding modes of ligands while holding the protein as a rigid structure. The PLANTSPLP algorithm was used to calculate the docking score [31] and more negative values indicate stronger binding.

\section{Statistical Analysis}

The results were expressed as mean \pm SEM (Standard Error of the Mean). Statistical analysis between groups was performed using Analysis of Variance ANOVA, followed by Bonferroni multiple comparisons test. The differences were considered statistically significant when $\mathrm{P}<0.05$. GraphPad Prism ${ }^{\circledR}$ Software version 5.0 was used. 


\section{Results}

\section{Effects of ConA and ConBr on Histopathological Changes of Experimental Acute Pancreatitis}

Treatment post-insult with both lectins protected the animals against acute pancreatitis caused by sodium taurocholate ( $\mathrm{Na}-\mathrm{TC})$. Thus ConA $(10 \mathrm{mg} / \mathrm{kg})$ and $\mathrm{ConBr}(10 \mathrm{mg} / \mathrm{kg})$ protected the pancreatic tissue against histopathological alterations, comprising increased neutrophilic infiltration - (Fig. 1a), oedema (Fig. 1b) and tissue necrosis (Fig. 1c) caused by Na-TC. ConA and ConBr reduced the total histological changes induced by Na-TC by $43.6 \%$ and $71.8 \%$, respectively, compared to controls (Fig. 1d). Photomicrographs show the histopathological changes caused by Na-TC (Fig. 1f) (black arrow: neutrophilic infiltrate; red arrow: edema) compared to the saline control group (Fig. 1e); ConA (Fig. 1g) and $\mathrm{ConBr}$ (Fig. $1 \mathrm{~h})$ protected pancreatic tissue in all parameters evaluated.

\section{Role of ConA and ConBr on MPO Activity in the Na-TC-induced Experimental Acute Pancreatitis}

Having observed the protective effects of lectins at a dose of $10 \mathrm{mg} / \mathrm{kg}$ on histopathological damage, a range of concentrations $(0.1 ; 1$ and $10 \mathrm{mg} / \mathrm{kg}$ ) were analyzed on pancreatic myeloperoxidase changes. Both lectins decreased the sodium taurocholate $\mathrm{Na}$-TC-induced elevation of myeloperoxidase in a dosedependent manner; the results of this analysis confirmed that the $10 \mathrm{mg} / \mathrm{kg}$ dose of ConA and $\mathrm{ConBr}$ showed higher efficacy with both molecules decreasing the MPO levels by $94.4 \%$ and $98.1 \%$, respectively, compared to Na-TC group, justifying its choice for subsequent analysis (Fig. 2a, b).

\section{Effects of ConA and ConBr on Amylase and Lipase Assay in the Na-TC-induced Experimental Acute Pancreatitis}

$\mathrm{Na}-\mathrm{TC}$ administration increased amylase and lipase by $81.3 \%$ and $73.0 \%$, respectively, compared to controls. ConA and ConBr treatment was protective, decreasing elevated amylase by $42.0 \%$ and $31.4 \%$, respectively, Similarly, $\mathrm{Na}-\mathrm{TC}$-induced rise of lipase was reduced by $55.0 \%$ and $63.0 \%$ by ConA and $\mathrm{ConBr}$ treatment, respectively (Fig. 3a, b).

ConA and ConBr Decrease Necrosis and Depolarization of Mitochondrial Membrane Potential $(\Delta \Psi \mathrm{m})$ Induced by TLCS in Pancreatic Acinar Cells

The percentage of necrotic cells after incubation with ConA or ConBr was similar to control. However, TLCS increased acinar cell necrosis by $66.9 \%$ compared to control. Incubation with ConA and $\mathrm{ConBr}$ decreased this rise by $45.0 \%$ and $44.9 \%$, respectively (Fig. $4 \mathrm{a}$, b). In separate experiments, the intense mitochondrial depolarization of acinar cells induced by TLCS was reduced by $62.1 \%$ and $56.5 \%$ prior incubation with ConA and ConBr, respectively (Fig. 5a, b).

Protective Effects of ConA and ConBr on TLCS-induced Necrosis is Dependent on Interaction with Mannose Residues 
The lectins anti-necrotic effects were abolished by the association of both molecules with their ligand sugar a-methyl mannoside (a-MM). No statistical difference between lectins and TLCS groups was observed. Application of a-MM per se did not induce acinar cell injury (Fig. 6).

\section{Interaction of ConA and $\mathrm{ConBr}$ with Monosaccharides and $\mathrm{N}$-glycans by Molecular Docking}

Docking of several $\mathrm{N}$-glycans to the crystal structures of $\mathrm{ConBr}$ and ConA indicated strong binding with a$\mathrm{MM}$, with scores of -48.6388 and -45.2614 , respectively. ConA demonstrated stronger binding to hybrid glycans-containing mannosidic residues, while $\mathrm{ConBr}$ demonstrated preferable binding to high mannose glycans, with scores of -47.5108 and -64.6829 , respectively. The highest interaction of ConA and $\mathrm{ConBr}$ with the glycan is showed in Fig. 7 and Tables 1 and 2 (Online Resource 1 and 2).

\section{Discussion}

This study has shown for the first time that treatment with ConA and ConBr lectins is protective against the detrimental inflammatory, biochemical and histopathological changes that occur during biliary acute pancreatitis. It is likely that a significant component of this beneficial activity resides in local actions of these biological molecules, since both protected pancreatic acinar cells against mitochondrial dysfunction and necrosis caused by TLCS. The protective actions were dependent, at least in part, on specific interactions with the lectin domain.

Acute pancreatitis is a necro-inflammatory disorder the main causal factor of which is the presence of gallstones within the distal common bile duct, allowing consequent reflux of bile into the pancreatic duct $[32,33]$ accounting for $30-60 \%$ of cases [34]. Retrograde administration of Na-TC into the pancreas of mice is a reliable, established experimental model of biliary acute pancreatitis, characterized by pancreatic inflammation with defined histopathological, inflammatory and biochemical changes [27]. Toxic precipitating agents such as bile acids cause acinar cell lesions; after intense stimulation with $\mathrm{Na}$ TC the pancreatic tissue becomes swollen, with tissue necrosis and prominent leukocyte infiltration apparent [11]. In the present study, ConA and ConBr protected against histopathological damage of the pancreas caused by Na-TC, with significantly reduced edema, necrosis and neutrophil infiltration. In accord, both lectins decreased MPO levels elevated in biliary AP, consistent with protection against neutrophil infiltration that causes tissue damage and aggravates the inflammatory lesions [35]. A marked increase in serum pancreatic lipase and amylase levels at 24 hours, characteristic of acinar cell damage during acute pancreatitis [36-38] was also reduced by treatment with ConA and ConBr.

Antinociceptive [22, 24]; and anti-inflammatory [39, 23]; properties of Diocleinae lectins, have previously been reported in animal experimental models. However, to-date there has been no study showing antiinflammatory activities of ConA and ConBr. Our current results demonstrate novel protective actions of ConA and ConBr to combat inflammation in experimental acute pancreatitis. Since the lectins were applied after acute pancreatitis had been instigated, rather than as pretreatment, new possibilities for therapeutic application are suggested; an important finding since there is currently no specific treatment for this debilitating and sometimes fatal disease. 
Pancreatic acinar cell necrosis is considered the initiating event of cell collapse fundamental for the onset of an inflammatory cascade in acute pancreatitis [40-43]. Bile acids cause local cell injury by the induction of sustained increases in cytosolic $\left[\mathrm{Ca}^{2+}\right]$ that reduce mitochondrial membrane potential and deplete cellular ATP, leading to acinar cell necrosis [5-10]. Mitochondrial dysfunction, involving formation of the permeability transition pore, is a core feature of acute pancreatitis [11] In isolated acinar cells ConA and $\mathrm{ConBr}$ protected against mitochondrial dysfunction, partially inhibiting mitochondrial depolarization induced by TLCS. These data are supported by studies showing the involvement of these lectins with mitochondrial function in other cell types e.g. after associating with the mannose moiety residing on a cell membrane glycoprotein in a liver tumor cell line, ConA was internalized to mitochondria via clathrinmediated endocytosis and promoted autophagic cell death [44]. In addition, ConA and ConBr promoted partial $\Delta \psi \mathrm{m}$ loss that triggered apoptosis in leukemic cells lines [20]. Consistent with an inhibition of $\triangle \psi \mathrm{m}$ depolarization induced by TLCS, ConA and ConBr significantly prevented TLCS-induced necrosis. Previously ConBr was found to protect against hippocampal cell death in mice induced by quinolinic acid, an action that involved inhibition of necrosis [45].

The surface of the pancreatic acinar cell contains several sugar residues including $\mathrm{N}$-acetyl-glucosamine, galactose and possibly also $\mathrm{N}$-acetyl-neuraminic acid in the apical region, and fucose, galactose, mannose and glucose residues in the basolateral region [46, 47]. Molecules such as ConA and $\mathrm{ConBr}$ are ligands of carbohydrates and can therefore bind on the surface of acinar cells, indicating a possible mechanism by which these lectins exerted their protective biological actions. The non-catalytic domain or carbohydrate recognition domain (CRD) of the lectins, also called the lectin domain, is the site at which lectins bind specifically and reversibly to carbohydrates and other substances that contain sugar moieties. Many of the biological activities of lectins in general are related to an interaction with sugars present on the cell surface [48]. Proof of participation of the lectin domain in processes of cell recognition and interaction has been shown by inhibition of the lectin effect by binding to its specific sugar/glycoconjugate $[22,23,24,39)$. ConA and ConBr are glucose/mannose ligands lectins which have had biological activities previously attributed to their lectin domain $[23,49,50]$. In this study, protective effects against TLCS-induced cell death were abolished after blocking the ConA and ConBr lectin domain, indicating that their actions are, at least partly, due to a direct interaction of the lectin domain with pancreatic acinar cells.

Diocleinae lectins exhibit high degree of homology in their primary structures and share many biochemical and structural features, such as evolutionarily conserved regions that characterize this group [51]. Differences in their biological activity may reflect not only small changes in the amino acid sequence of the CRD, but also different conformations of the site itself and adjacent loops [51, 52]. The comparative study of lectins from the same subfamily is useful to broaden knowledge about biological structure-activity relationships of these proteins. The lectins evaluated in this study study exhibit $99 \%$ structural similarity with only two amino acid residues different; glycine (Gly) 58 and Gly 70 in ConBr are replaced by aspartate (Asp) and alanine (Ala) in ConA, respectively, with none of these residues close to the carbohydrate binding site. Both are tetramers at neutral $\mathrm{pH}$ or above 5.5, and dimers below 5.5 [53]. 
ConA and $\mathrm{ConBr}$ applied under the same conditions of physiological $\mathrm{pH}$ would present as tetramers and thus retain their ability to bind to carbohydrate residues on the cell surface; similar activities of ConA and ConBr were observed in this study. Molecular docking demonstrated that both lectins are capable of interaction with most glycans that contain mannose residues, with some differences in score apparent. This might explain small differences in biological activities previously reported despite the high structural similarity of these lectins $[12,54-56]$. However, in the present study, ConA and ConBr exhibited a very similar pattern of results in all assays, in agreement with prior analyses with ConA and $\mathrm{ConBr}$ in leukemia cell lines [20].

In summary, our findings demonstrate for the first time that ConA and $\mathrm{ConBr}$, applied after the initiation of biliary acute pancreatitis, are protective against inflammation and tissue damage. These actions are partly mediated via interaction of the lectin domain with sugar residues present on the acinar cells, leading to protection against mitochondrial dysfunction and acinar cell necrosis. Further studies are warranted to better understand the underlying mechanisms of action of these anti-inflammatory molecules and assess their potential for therapeutic development.

\section{Declarations}

\section{Funding}

This research was supported by Conselho Nacional de Desenvolvimento Científico e Tecnológico (CNPq), Coordenação de Aperfeiçoamento de Pessoal de Nível Superior (CAPES) and Fundação Cearense de Apoio ao Desenvolvimento Científico e Tecnológico (FUNCAP).

\section{Conflicts of interest}

The authors declare that not have conflict of interest.

\section{Ethics approval}

All procedures were approved by the Animal Use Ethics Committee (CEUA) of the Federal University of Ceara (protocol n 99/2013).

\section{Consent to participate}

All authors declare participation in the study.

\section{Consent for publication}

All authors declare consent for publication of study.

\section{Availability of data and material}


The authors confirm that the data supporting the findings of this study are available within the article and its supplementary materials.

\section{Code availability}

Not applicable

\section{Authors' contributions}

All authors contributed to the study conception and design. Material preparation, data collection and analysis were performed by Samara Rodrigues Bonfim Damasceno Oliveira; Marielle Pires Quaresma; Patrícia da Silva Pantoja; Vinicius José da Silva Osterne; Jorge Luis Almeida Correia. The first draft of the manuscript was written by Samara Rodrigues Bonfim Damasceno Oliveira; Pedro Marcos Gomes Soares and all authors commented on previous versions of the manuscript. All authors read and approved the final manuscript.

\section{References}

1. Dedemadi, G., M. Nikolopoulos, I. Kalaitzopoulos, and G. Sgourakis. 2016. Management of patients after recovering from acute severe biliary pancreatitis. World J Gastroenterol 22: 7708-7717.

2. Huber, H., and H. Algül. 2019. Treatment of acute necrotizing pancreatitis. Internist (Berl) 60: 226234.

3. Banks, P.A., T.L. Bollen, C. Dervenis, H.G. Gooszen, , C.D. Johnson, M.G. Sarr, G.G. Tsiotos, and S.S. Vege. 2013. Classification of acute pancreatitis-2012: revision of the Atlanta classification and definitions by international consensus. Gut 62: 102-111.

4. Saluja, A., B. Hofbauer, Y. Yamaguchi, K. Yamanaka, and M. Steer. 1996. Induction of apoptosis reduces the severity of caerulein-induced pancreatitis in mice. Biochem Biophys Res Commun 220: 875-878.

5. Booth, D.M., J.A. Murphy, R. Mukherjee, M. Awais, J.P. Neoptolemos, O.V. Gerasimenko, A.V. Tepikin, O.H. Petersen, R. Sutton, and D.N. Criddle. 2011a. Reactive oxygen species induced by bile acid induce apoptosis and protect against necrosis in pancreatic acinar cells. Gastroenterology 140: 2116-2125.

6. Meyrignac, O., S. Lagarde, B. Bournet, F.Z. Mokrane, L. Buscail, H. Rousseau, and P. Otal. 2015. Acute pancreatitis: extrapancreatic necrosis volume as early predictor of severity. Radiology 276: 119-128.

7. Perides, G., J.M. Laukkarinen, G. Vassileva, and M.L. Steer. 2010. Biliary acute pancreatitis in mice is mediated by the G-protein-coupled cell surface bile acid receptor Gpbar1. Gastroenterology 138: 715725.

8. Gerasimenko, J.V., S.E. Flowerdew, S.G. Voronina, T.K. Sukhomlin, A.V. Tepikin, O.H. Petersen, and O.V. Gerasimenko. 2006 Bile acids induce $\mathrm{Ca}(2+)$ release from both the endoplasmic reticulum and 
acidic intracellular calcium stores through activation of inositol trisphosphate receptors and ryanodine receptors. J Biol Chem 281: 40154-40163.

9. Voronina, S.G., O.V. Gryshchenko, O.V. Gerasimenko, A.K. Green, O.H. Petersen, and A.V. Tepikin. 2005. Bile Acids Induce a Cationic Current, Depolarizing Pancreatic Acinar Cells and Increasing the Intracellular Na+ Concentration. J Biol Chem 280: 1764-1770.

10. Booth, D.M., R. Mukherjee, R. Sutton, and D.N. Criddle. 2011b Calcium and reactive oxygen species in acute pancreatitis: friend or foe? Antioxidants \& Redox Signaling 15: 2683-2698.

11. Mukherjee, R., O.A. Mareninova, I.V. Odinokova, W. Huang, J. Murphy, M. Chvanov, M.A. Javed, L. Wen, D.M. Booth, M.C. Cane, M. Awais, B. Gavillet, R.M. Pruss, S. Schaller, J.D. Molkentin, A.V. Tepikin, O.H. Petersen, S.J. Pandol, I. Gukovsky, D.N. Criddle, A. Gukovskaya, and R. Sutton. 2016. Mechanism of mitochondrial permeability transition pore induction and damage in the pancreas: inhibition prevents acute pancreatitis by protecting production of ATP. Gut 65: 1333-1346.

12. Cavada, B.S., T. Barbosa , S. Arruda, T.B. Grangeiro, and M. Barral-Netto. 2001. Revisiting proteus: do minor changes in lectin structure matter in biological activity? Lessons from and potential biotechnological uses of the Diocleinae subtribe lectins. Curr Protein Pept Sci 2: 123-135.

13. Cavada, B.S., V.J.S. Osterne, C.F. Lossio, V.R. Pinto-Junior, M.V. Oliveira, M.T.L. Silva, R.B. Leal, and K.S. Nascimento. 2019 One century of ConA and 40 years of ConBr research: A structural review. Int J Biol Macromol 1: 901-911.

14. Lin, S.S., and I.B. Levitan. 1991. Concanavalin A: a tool to investigate neuronal plasticity. Trends Neurosci 14: 273-277.

15. Scherer, W.J., and S.B. Udin. 1994. Concanavalin A reduces habituation in the tectum of the frog. Brain Res 667: 209-215.

16. Everts, I., R. Petroski, P. Kizelsztein, V.I. Teichberg, S.F. Heinemann, and M. Hollmann. 1999. Lectininduced inhibition of desensitization of the kainate receptor GluR6 depends on the activation state and can be mediated by a single native or ectopic N-linked carbohydrate side chain. J Neurosci 19: 916-927.

17. Jacques, A.V., D.K. Rieger, M. Maestri, M.W. Lopes, T.V. Peres, F.M. Gonçalves, D.Z. Pedro, C.I. Tasca, M.G. López, J. Egea, K.S. Nascimento, B.S. Cavada, and R.B. Leal. 2013 Lectin from Canavalia brasiliensis (ConBr) protects hippocampal slices against glutamate neurotoxicity in a manner dependent of PI3K/Akt pathway. Neurochem Int 62: 836-842.

18. Liu, B., C.Y. Li, H.J. Bian, M.W. Min, L.F. Chen, and J.K. Bao. 2009 Antiproliferative activity and apoptosis-inducing mechanism of Concanavalin A on human melanoma A375 cells. Arch Biochem Biophys 482: 1-6.

19. Silva, F.O., P.D. Santos, E.O. Figueirôa, C.M. De Melo, J.K. De Andrade Lemoine Neves, F.V. Arruda, J.B. Cajazeiras, K.S. Do Nascimento, E.H. Teixeira, B.S. Cavada, A.L. Porto, and V.R. Pereira. 2014. Antiproliferative effect of Canavalia brasiliensis lectin on B16F10 cells. Res Vet Sci 96: 276-282.

20. Faheina-Martins, G.V., A.L. Da Silveira, B.C. Cavalcanti, M.V. Ramos, M.O. Moraes, C. Pessoa, and D.A.M. Araújo. 2012 Antiproliferative effects of lectins from Canavalia ensiformis and Canavalia 
brasiliensis in human leukemia cell lines. Toxicol In Vitro 26: 1161-1169.

21. Silva, A.F., M.P. Matos, M.T. Ralph, D.L. Silva, N.M. De Alencar, M.V. Ramos, and J.V. Lima-Filho. (2016) Comparison of immunomodulatory properties of mannose-binding lectins from Canavalia brasiliensis and Cratylia argentea in a mice model of Salmonella infection. Int Immunopharmacol 31: 233-238.

22. Pinto, N.V., B.S. Cavada, L.F. Brito, R.I. Pereira, M.T. Da Silva, R.R. Castro, A. De Freitas Pires, and A.M. Assreuy. 2013a. Effects of Canavalia lectins on acute inflammation in sensitized and non-sensitized rats. Inflammation 36: 713-722.

23. Pinto, N.V., C.F. Santos, B.S. Cavada, K.S. Do Nascimento, J.F.N. Pereira, A. D. F. Pires, and A.M. Assreuy. 2013b. Homologous Canavalia lectins elicit different patterns of antinociceptive responses. Nat Prod Commun 11: 1621-1614.

24. Pires, A.F., A.M. Assreuy, É.A. Lopes, N.R. Celedônio, C.E. Soares, N.V. Rodrigues, P.L. Sousa, R.G. Benevides, C.S. Nagano, B.S. Cavada, J.H. Leal-Cardoso, A.N. Coelho-De-Souza, and C.F. Santos. 2013. Opioid-like antinociceptive effects of oral administration of a lectin purified from the seeds of Canavalia brasiliensis. Fundam Clin Pharmacol 27: 201-209.

25. Carlini, C.R., and J.A. Guimarães. 1981 Isolation and characterization of a toxic protein from Canavalia ensiformis(jack bean) seeds, distinct from concanavalin A. Toxicon19: 667-675.

26. Moreira, R.A., and B.S. Cavada. (1984) Lectin from Canavalia brasiliensis Mart. Isolation, characterization and behavior during germination. Biologia Plantarum 26: 113-120.

27. Laukkarinen, J.M., G.J. Van Acker, E.R. Weiss, M.L. Steer, and G.A. Perides. 2007. Mouse model of acute biliary pancreatitis induced by retrograde pancreatic duct infusion of Na-taurocholate. Gut 56: 1590-1598.

28. Dawra, R., Y.S. Ku, and R. Sharif. 2008. An improved method for extracting myeloperoxidase and determining its activity in the pancreas and lungs during pancreatitis. Pancreas 37: 62-68.

29. Huang, W., D.M. Booth, M.C. Cane, M. Chvanov, M.A. Javed, V.L. Elliott, J.A. Armstrong, H. Dingsdale, N. Cash, Y. Li, W. Greenhalf, R. Mukherjee, B.S. Kaphalia, M. Jaffar, O.H. Petersen, A.V. Tepikin, R. Sutton, and D.N. Criddle. 2014. Fatty acid ethyl ester synthase inhibition ameliorates ethanol-induced Ca2+-dependent mitochondrial dysfunction and acute pancreatitis. Gut 63: 1313-1324.

30. Wallace, A.C., R.A. Laskowski, J. Singh, and J.M. Thornton. 1996. Molecular recognition by proteins: protein-ligand interactions from a structural perspective. Biochem Soc Trans 24: 280-284.

31. Korb, O., T. Stützle, and T.E. Exner. 2009. Empirical scoring functions for advanced protein-ligand docking with PLANTS. J Chem Inf Model 49: 84-96.

32. Opie, E.L., and J.C. Meakins. 1909. Data concerning the etiology and pathology of hemorrhagic necrosis of the pancreas (acute hemorrhagic pancreatitis). J Exp Med 11: 561-578.

33. Shah, A.P., M.M. Mourad, and S.R. Bramhall. 2018. Acute pancreatitis: current perspectives on diagnosis and management. J Inflamm Res 11: 77-85.

34. Leppäniemi, A., M. Tolonen, A. Tarasconi, H. Segovia-Lohse, E. Gamberini, A.W. Kirkpatrick, C.G. Ball, N. Parry, M. Sartelli, D. Wolbrink, H. van Goor, G. Baiocchi, L. Ansaloni, W. Biffl, F. Coccolini, S. Di 
Saverio, Y. Kluger, E. Moore, and F. Catena. 2019. WSES guidelines for the management of severe acute pancreatitis. World J Emerg Surg 14: 27.

35. Aratani, Y. 2018. Myeloperoxidase: Its role for host defense, inflammation, and neutrophil function. Arch Biochem Biophys 640: 47-52.

36. Lippi, G., M. Valentino, and G. Cervellin. 2012. Laboratory diagnosis of acute pancreatitis: in search of the holy grail. Crit Rev Clin Lab Sci 49:18-31.

37. Rompianesi, G., A. Hann, O. Komolafe, S.P. Pereira, B.R. Davidson, and K.S. Gurusamy. 2017. Serum amylase and lipase and urinary trypsinogen and amylase for diagnosis of acute pancreatitis. Cochrane Database Syst Rev 4: CD012010.

38. Huang, W., M.C. Cane, R. Mukherjee, , P. Szatmary, X. Zhang, V. Elliott, Y. Ouyang, M. Chvanov, D. Latawiec, L. Wen, D.M. Booth, A.C. Haynes, O.H. Petersen, A.V. Tepikin, D.N. Criddle, and R. Sutton. 2017. Caffeine protects against experimental acute pancreatitis by inhibition of inositol 1,4,5trisphosphate receptor-mediated Ca2+ release. Gut 66: 301-313.

39. Assreuy, A.M., M.D. Shibuya, G.J. Martins, M.L. De Souza, B.S. Cavada, R.A. Moreira, J.T. Oliveira, R.A. Ribeiro, and C.A. Flores. 1997 Anti-inflammatory effect of glucose-mannose binding lectins isolated from Brazilian beans. Mediators Inflamm 6: 201-210.

40. Criddle, D.N., M.G.T. Raraty, J.P. Neoptolemos, A.V. Tepikin, O.H. Petersen, and R. Sutton. (2004) Ethanol toxicity in pancreatic acinar cells: Mediation by nonoxidative fatty acid metabolites. PNAS 10: 10738-10743.

41. Criddle, D.N., J.V. Gerasimenko, H.K. Baumgartner, M. Jaffar, S. Voronina, R. Sutton, O.H. Petersen, and O.V. Gerasimenko. 2007. Calcium signalling and pancreatic cell death: apoptosis or necrosis? Cell Death Differ 14: 1285-1294.

42. Mareninova, O.A., K.F. Sung, P. Hong, A. Lugea, S.J. Pandol, I. Gukovsky, and A.S. Gukovskaya. 2006. Cell death in pancreatitis: caspases protect from necrotizing pancreatitis. $J$ Biol Chem 281: 33703381.

43. Szatmary, P., T. Liu, S.T. Abrams, S. Voronina, L. Wen, M. Chvanov, W. Huang, G. Wang, D.N. Criddle, A.V. Tepikin, C.H. Toh, and R. Sutton. 2017. Systemic histone release disrupts plasmalemma and contributes to necrosis in acute pancreatitis. Pancreatology 17: 884-892.

44. Lei, H.Y., and C. Chang. (2009) Lectin of Concanavalin A as an antihepatoma therapeutic agent. $J$ Biomed Sci 16: 10.

45. Russi, M.A., S. Vandresen-Filho, D.K. Rieger, A.P. Costa, M.W. Lopes, R.M. Cunha, E.H. Teixeira, K.S. Nascimento, B.S. Cavada, C.I. Tasca, and R.B. Leal. 2012. ConBr, a lectin from Canavalia brasiliensis seeds, protects against quinolinic acid-induced seizures in mice. Neurochem Res 37: 288-297.

46. Jonas, L., C. Ostwald, W. Griethe, and G. Letko. 1991. Light and electron microscopic studies of the lectin binding on the glycocalys of rat pancreatic cells. I. Normal tissue and isolated cells. Acta histochem 91: 213-214.

47. Jonas, L., and H.P. Putzke. 1992. Light and electron microscopic studies of lectin binding to the glycocalyx of rat pancreatic cells. II. Light microscopic changes after induction of an olive-oil 
pancreatitis. Acta histochem 93: 388-396.

48. Mishra, A., A. Behura, S. Mawatwal, A. Kumar, L. Naik, S.S. Mohanty, D. Manna, P. Dokania, A. Mishra, S.K. Patra, and R. Dhiman. 2019. Structure-function and application of plant lectins in disease biology and immunity. Food Chem Toxicol. 134: 110827.

49. Assreuy, A.M., S.R. Fontenele, A.D.F. Pires, D.C. Fernandes, N.V. Rodrigues, E.H. Bezerra, T.R. Moura, K.S. Do Nascimento, and B.S. Cavada. 2009. Vasodilator effects of Diocleinae lectins from the Canavalia genus. Naunyn-Schmied Arch Pharmacol 380: 509-521.

50. Burgess, A., J.P. Mornon, G. De Saint-Basile, and I. Callebaut. 2009. A concanavalin A-like lectin domain in the CHS1/LYST protein, shared by members of the BEACH family. Bioinformatics 25: 1219-1222.

51. Delatorre, P., B.A.M. Rocha, C.A.A. Gadelha, T. Santi-Gadelha, J.B. Cajazeiras, E.P. Souza, and K.S. Nascimento. 2006. Crystal structure of a lectin from Canavalia maritima (ConM) in complex with trehalose and maltose reveals relevant mutation in ConA-like lectins. J Struct Bio/ 154: 280-286.

52. Delatorre, P., B.A.M. Rocha, E.P. Souza, T.M. Oliveira, G.A. Bezerra, and F.B.B.T. Moreno Freitas. (2007) Structure of a lectin from Canavalia gladiata seeds: new structural insights for old molecules. BMC Struct Biol 7: 52-60.

53. Agrawal, B.B.L., and I.J. Goldstein. 1965. Specific binding of concanavalin A to cross linked dextran gels. Biochem J 96: 23-25.

54. Andrade, J.L., S. Arruda, T. Barbosa, L. Paim, M.V. Ramos, and B.S. Cavada. 2009. Lectin-induced nitric oxide production. Cell Immunol 194: 98-102.

55. Barauna, A.C., M.P. Kaster, B.T. Heckert, K.S. Nascimento, F.M. Rossi, E.H. Teixeira, B.S. Cavada, A.L.S. Rodrigues, and R.B. Leal. 2006. Antidepressant-like effect of lectin from Canavalia brasiliensis (ConBr) administered centrally in mice. Pharmacol Biochem Behav 85: 160-169.

56. Barbosa, T., S. Arruda, B.S. Cavada, T.B. Grangeiro, L.A.R. Freitas, and M. Barral Netto. 2001. In vivo lymphocyte activation and apoptosis by lectins of the Diocleinae subtribe. Mem Inst Oswaldo Cruz 96: 673-678.

\section{Figures}



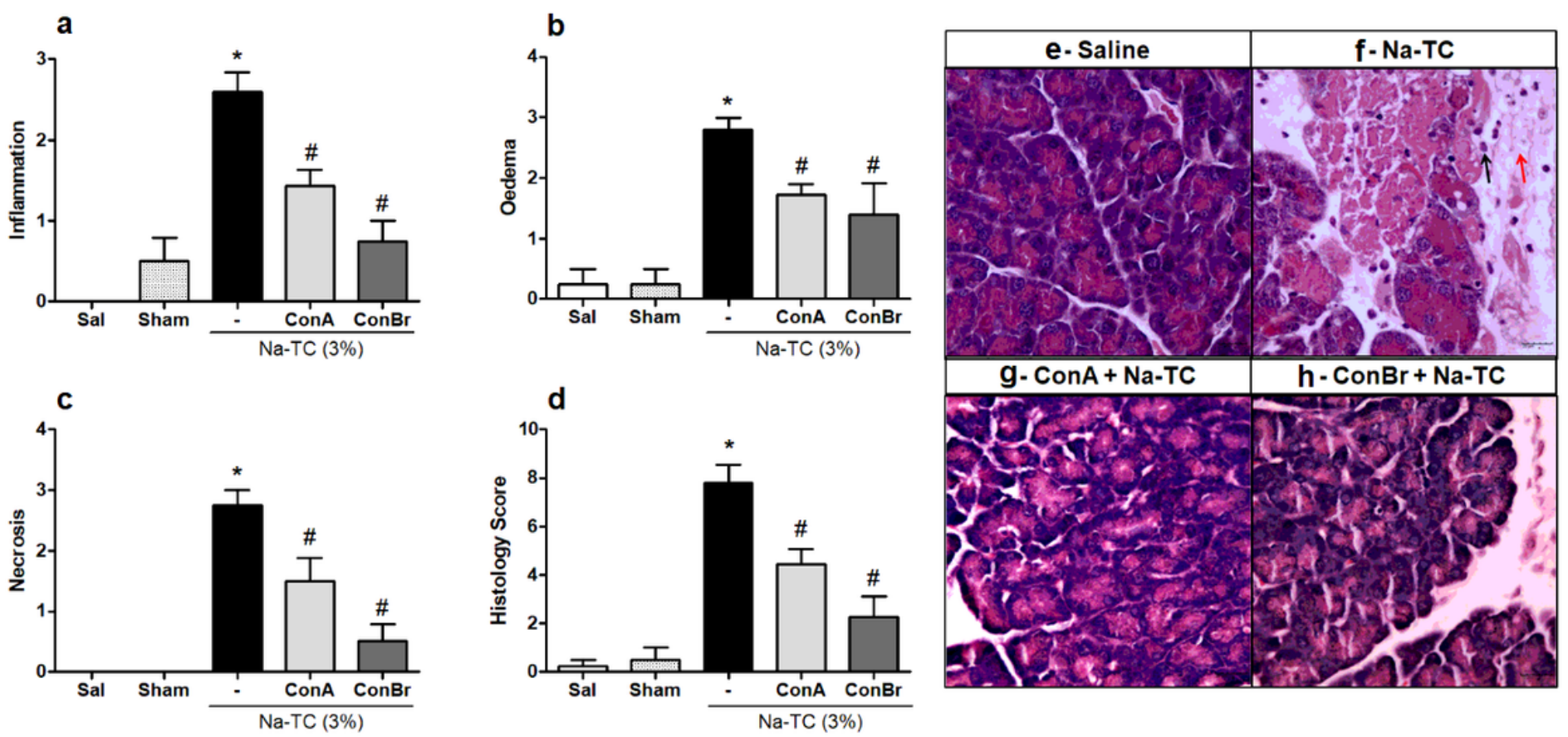

Figure 1

ConA and $\mathrm{ConBr}$ protect against histopathological damage caused by Na-TC in experimental acute pancreatitis in mice. Histopathological analysis of the aspects of inflammation (a), Oedema (b), Necrosis (c) and Total scores (d). Data were expressed as mean \pm standard error of the mean (SEM) of an experimental "n" of at least 8 animals. * $p<0.05$ vs. Sal group; \# $p<0.05$ vs. Na-TC group. One-way ANOVA followed by Bonferroni post-test. Photomicrographs of the histopathological analysis (increase of $400 \mathrm{X}$ ) are shown in E: representing the Saline group; F: representing the Na-TC group; G: representing the $\mathrm{ConA}+\mathrm{Na}-\mathrm{TC}$ group and $\mathrm{H}$ : representing the $\mathrm{ConBr}+\mathrm{Na}-\mathrm{TC}$ group. Black arrow: indicates presence of neutrophil infiltrate. Red arrow: indicates edema

a

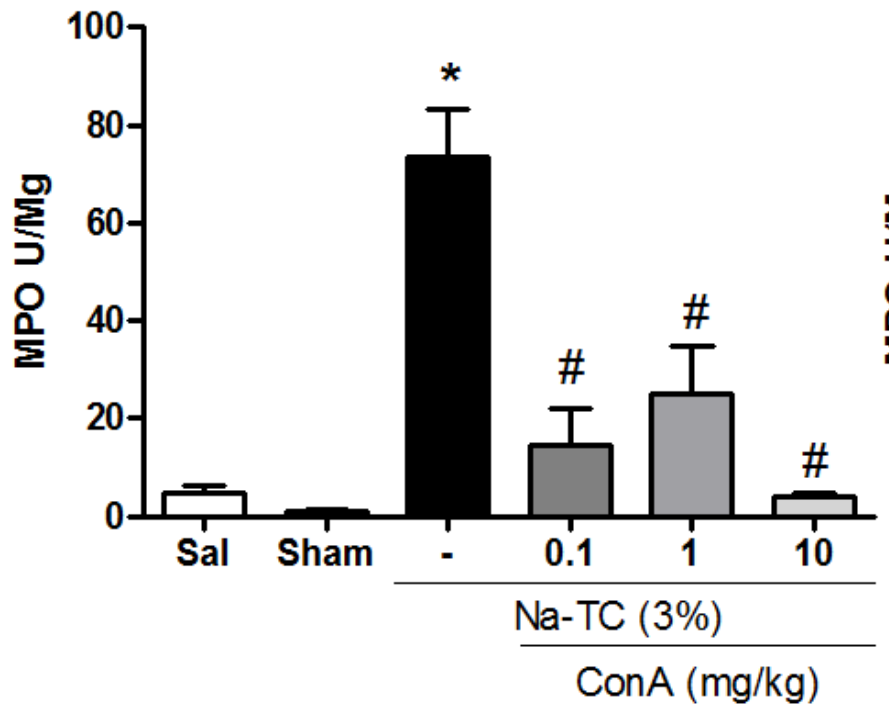

b

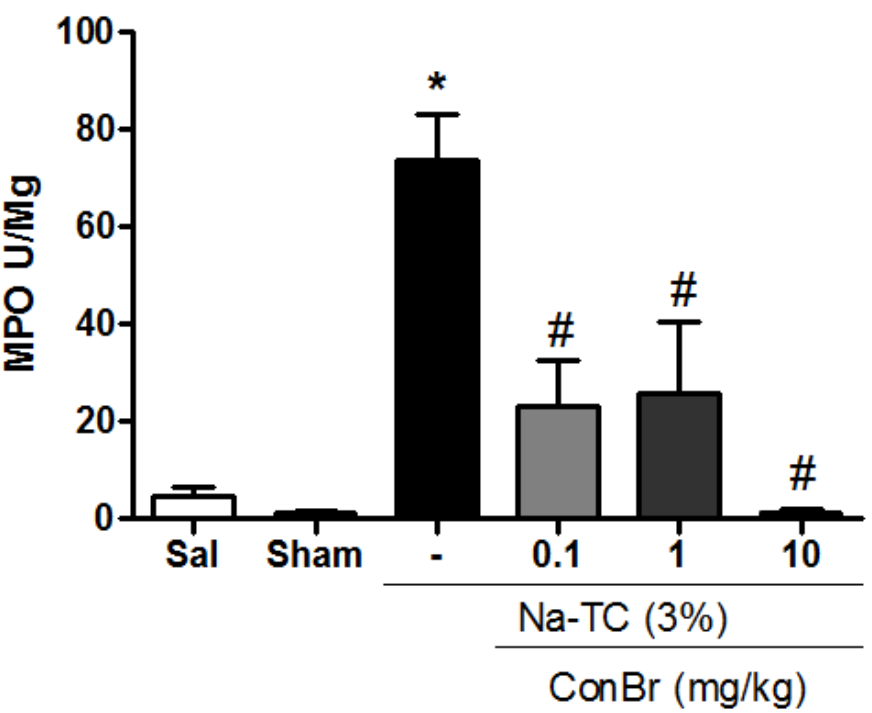


Figure 2

ConA and ConBr prevent the increased myeloperoxidase (MPO) in experimental acute pancreatitis induced by $\mathrm{Na}-\mathrm{TC}$, in a dose-dependent manner. Data were expressed as mean \pm standard error of the mean (SEM) of an experimental " $n$ " of at least 8 animals. ${ }^{*} p<0.05$ vs. Sal group; $\# p<0.05$ vs. Na-TC group. One-way ANOVA followed by Bonferroni post-test

a

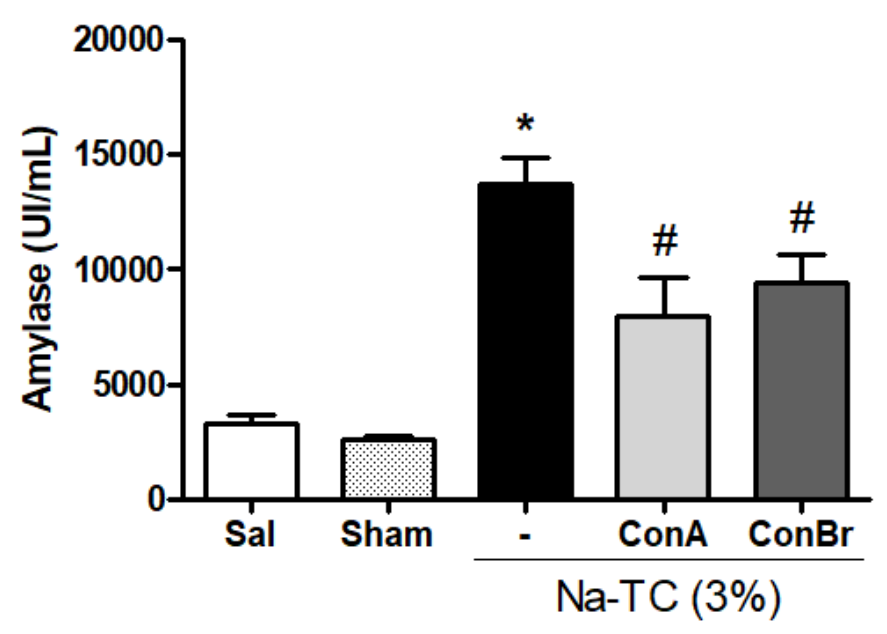

b

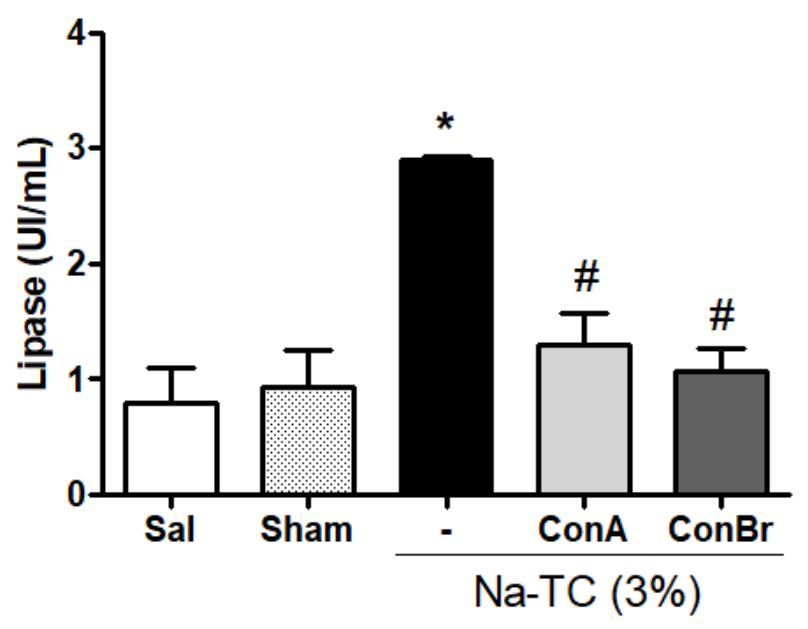

Figure 3

ConA and $\mathrm{ConBr}$ decrease the levels of amylase and lipase in experimental acute pancreatitis induced by Na-TC. Amylase (a) and lipase (b). Data were expressed as mean \pm standard error of the mean (SEM) of an experimental " $n$ " of at least 8 animals. * $p<0.05$ vs. Sal group; $\# p<0.05$ vs. Na-TC group. One-way ANOVA followed by Bonferroni post-test 


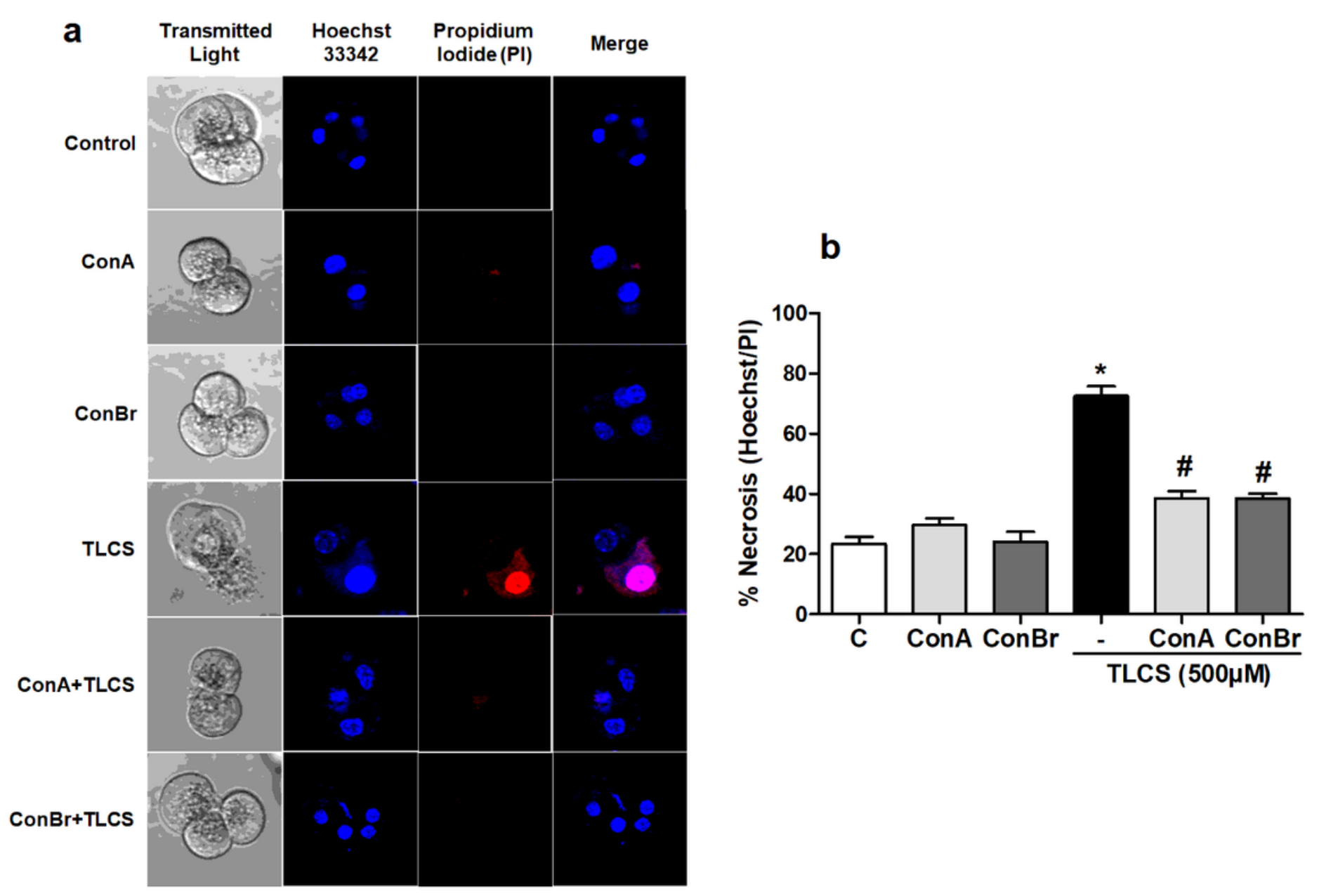

\section{Figure 4}

ConA and ConBr protect against pancreatic acinar cells necrosis induced by TLCS. The image panel in a illustrates in the first column: representative pancreatic acinar cells in transmitted light; second column: nuclei of total cells labeled with Hoechst 33342 (blue staining); third column: necrotic cells, labeled nuclei with PI (red staining) and fourth column: overlapping images (merge), facilitating visualization and quantification of cell death. Images obtained with FluoViewTM 1000 confocal microscope - Olympus, 400X magnification. (b) Necrosis percentage (ConA and ConBr + TLC-S). Mean \pm SEM of 15 fields in triplicate. Necrosis (\%) was given by the ratio of cells stained with Hoechst 33342 and $\mathrm{Pl}$. ${ }^{\star} \mathrm{p}<0.05$ vs. control (C); \#p <0.05 vs. TLCS. One-way ANOVA and Bonferroni test 


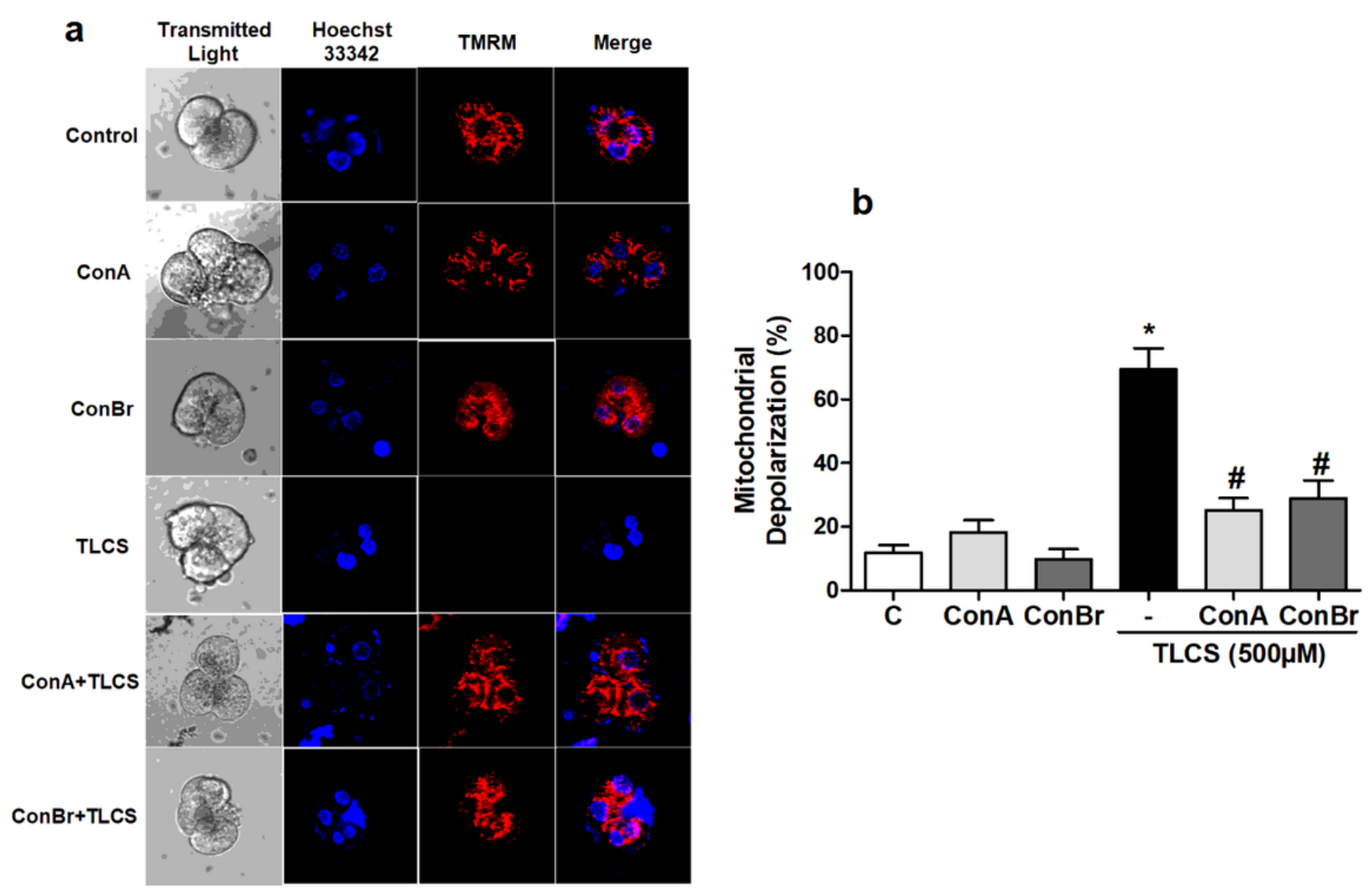

Figure 5

ConA and $\mathrm{ConBr}$ reduce the depolarization of mitochondrial membrane potential of acinar cells induced by TLCS. The image panel in a illustrates in the first column: representative pancreatic acinar cells in transmitted light; second column: nuclei of total cells labeled with Hoechst 33342 (blue staining); third column: mitochondria labeled with TMRM (red staining); fourth column: overlapping images (merge), facilitating visualization and quantification of cells. Images obtained with FluoViewTM 1000 confocal microscope - Olympus, 400X magnification. (b) Percentage (\%) of mitochondrial depolarization (ConA and $\mathrm{ConBr}+\mathrm{TLCS})$. Mean \pm SEM of 15 fields in triplicate. The percentage (\%) of mitochondrial depolarization is given by the ratio of cells labeled with Hoechst 33342 and TMRM, where a decrease in relative fluorescence of TMRM represents mitochondrial depolarization. ${ }^{\star} p<0.05$ vs. control (C); \#p $<0.05$ vs. TLC-S. One-way ANOVA and Bonferroni test 


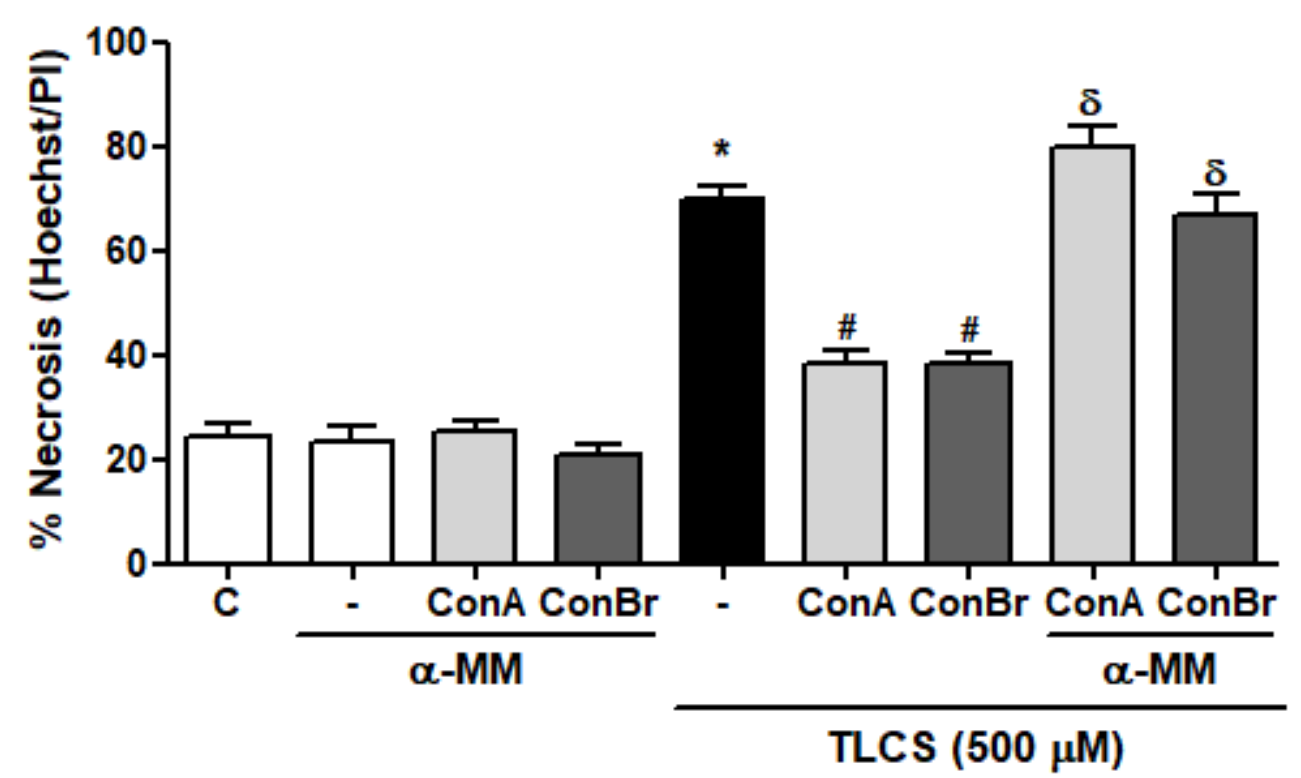

Figure 6

Antinecrotic effect of ConA and $\mathrm{ConBr}$ is lectin domain dependent. Data are expressed as mean \pm standard error of the mean (SEM) of the count of 15 image fields obtained under a FluoViewTM 1000 Olympus confocal microscope, repeated in triplicate. The percentage of necrosis is given by the ratio of cells labeled with Hoechst 33342 and propidium iodide (PI). * $p<0.05$ vs control group (C); $\# p<0.05$ vs SATC group; $\delta p<0.05$ vs ConA and ConBr groups. One-way ANOVA followed by Bonferroni posttest 
a)
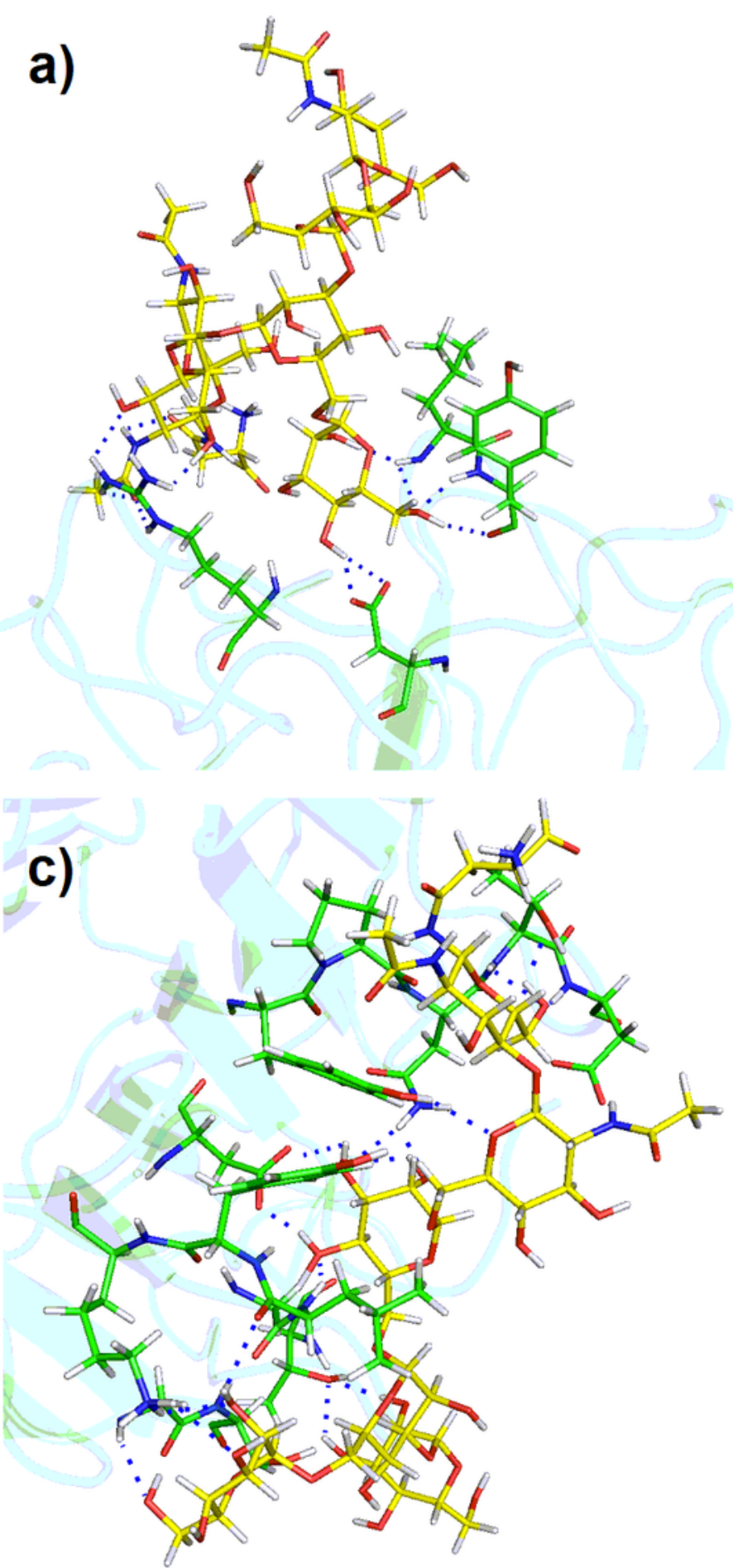

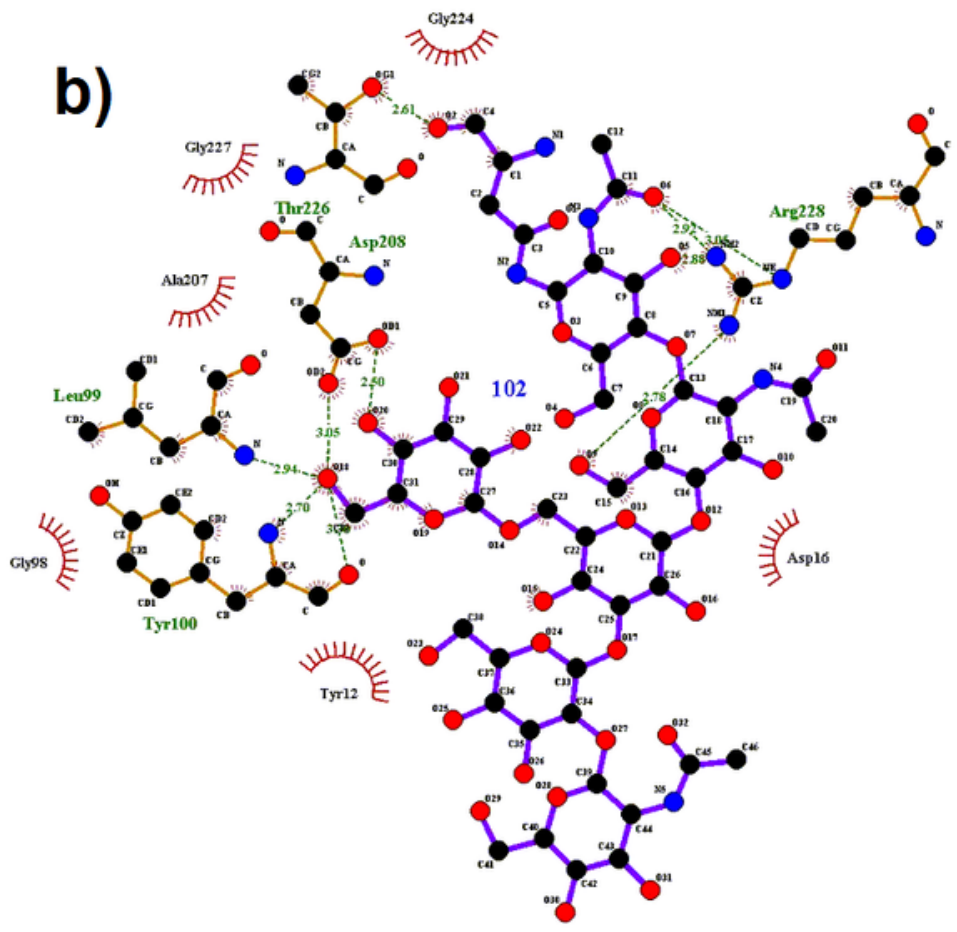

d)

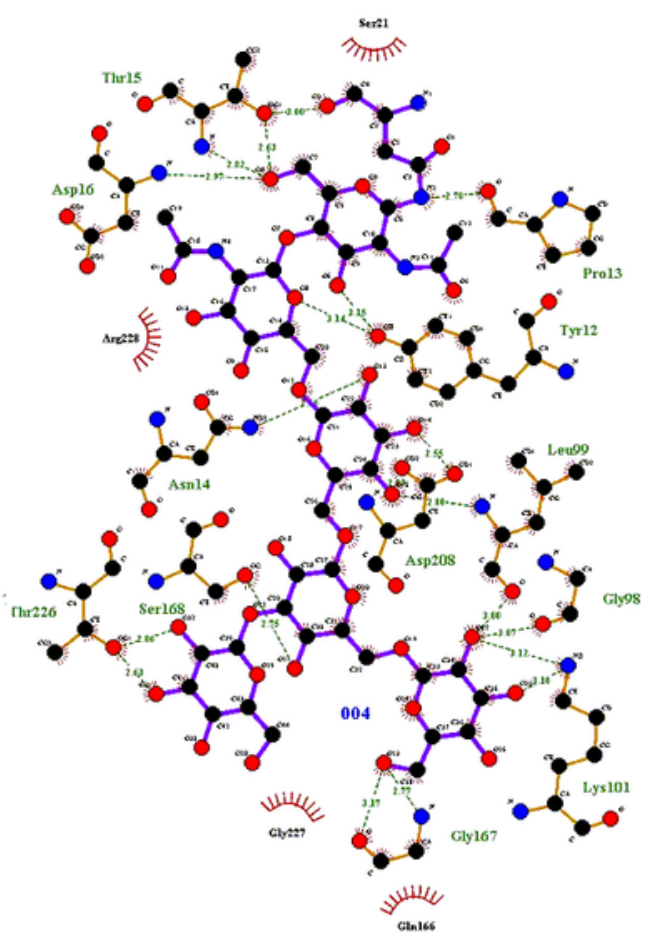

Figure 7

Molecular docking of ConA and ConBr with $\mathrm{N}$-glycans. a) Representation of ConA with the glycan number 102. b) Ligplot representation of ConA-102 complex. c) Representation of $\mathrm{ConBr}$ with the glycan number 004. d) Ligplot representation of ConBr-004 complex. Protein and ligands are in stick representation with carbons represented in green and yellow, respectively. Polar contacts are represented as blue dashes 


\section{Supplementary Files}

This is a list of supplementary files associated with this preprint. Click to download.

- Supplementary.Inflammation.doc 